\title{
Quaker Business Ethics as MacIntyrean Tradition
}

\author{
Nicholas Burton ${ }^{1} \cdot$ Matthew Sinnicks ${ }^{2}$ (1)
}

Received: 4 May 2020 / Accepted: 12 December 2020 / Published online: 16 January 2021

(c) The Author(s) 2021

\begin{abstract}
This paper argues that Quaker business ethics can be understood as a MacIntyrean tradition. To do so, it draws on three key MacIntyrean concepts: community, compartmentalisation, and the critique of management. The emphasis in Quaker business ethics on finding unity, as well as the emphasis that Quaker businesses have placed on serving their local areas, accords with MacIntyre's claim that small-scale community is essential to human flourishing. The emphasis on integrity in Quaker business ethics means practitioners are well-placed to resist the compartmentalising pressures of contemporary work. Quaker business ethics is also highly critical of the manipulative forms of management that MacIntyre regards as dominant. As such, Quaker business ethics provides evidence that more morally ameliorative forms of running business organisations is possible, even if they remain difficult to achieve.
\end{abstract}

Keywords Quakers · MacIntyre · Community · Compartmentalisation · Management

\section{Introduction}

In this paper we explore the Quaker tradition in business and business ethics. Other religious traditions have been the focus of recent work in business ethics, for instance Islam (Murphy and Smolarski 2020; Sidani and Al Ariss 2015), Confucianism (Koehn 2001; Romar 2004), Buddhism (Gould 1995; Pace 2013), Hinduism (Poruthiyil 2020), and there is also a significant body of work on Catholicism in business ethics (e.g. Sison et al. 2016; Bernacchio 2019). While there has been some research on Quakerism in the business ethics literature, such as Wagner-Tsukamoto (2008) who draws on Quakerism as an example of behavioural business ethics, we believe there is scope for a more detailed examination of Quaker business ethics that focuses on its philosophical and ethical commitments.

To do so, we draw attention to the overlap between Quaker business ethics and the thought of Alasdair

Matthew Sinnicks

matthew.sinnicks@york.ac.uk

Nicholas Burton

n.burton@nortumbria.ac.uk

1 Northumbria University, City Campus East 1, Newcastle NE1 8ST, UK

2 The York Management School, University of York, Freboys Lane, York YO10 5GD, UK
MacIntyre, whose work has been cited more than any other virtue ethicist in the business ethics literature (Ferrero and Sison 2014), with After Virtue (2007) being the focus of most of this scholarly attention (Beadle 2017). While Quakers share similar testimonies throughout the world, Quaker theology has varied interpretations. In this paper we assume a "Liberal Quaker" theology (Dandelion 2004), and focus in particular on UK Quakers. We highlight how Quakerism fits within MacIntyre's conception of traditions, and then explore three aspects of MacIntyre's thought that are especially relevant to Quaker business ethics: community, compartmentalisation, and the critique of manipulative management. These aspects reflect both the individual and social characteristics of Quakerism, and the rejection of the sacred/ secular binary that urges Quakers to "Bring the whole of your life under the ordering of the spirit of Christ... Let your worship and your daily life enrich each other" (Quakers in Britain 1995, 1.02).

In terms of community, the emphasis on discernment and finding unity, and the emphasis Quaker businesses have placed on serving their communities, accords with MacIntyre's claim that small-scale and egalitarian community is essential to the achievement of human flourishing. Second, according to MacIntyre, contemporary culture creates a pressure to compartmentalise our lives between various roles, which is turn undermines our moral agency as we become unable to adjudicate between competing demands. 
The emphasis on integrity, and the continuity between spiritual and worldly life in Quaker business ethics means practitioners are well-placed to resist the compartmentalising pressures of contemporary work, even though they are not entirely immune to them. Finally, Quaker business ethics is also highly critical of the manipulative forms of management that MacIntyre regards as dominant, and Quaker business practice also provides evidence that more morally ameliorative forms of running business organisations are possible even if they remain difficult to achieve. Research which draws on MacIntyre and seeks to connect religion and business ethics has, in line with MacIntyre's own religious convictions, focussed primarily on Catholicism (e.g. Moore et al. 2014; Velasquez and Brady 1997; McCann and Brownsberger 1990). Following Chu and Moore's (2020) connection of MacIntyre's thought to the Confucian tradition, we connect it to Quakerism, and thus hope to add to the diversity of voices in the conversation about business ethics, religion, and virtue.

\section{The Quaker Tradition}

Quakers played a central role in the development of a variety of industries in the eighteenth and nineteenth centuries, with perhaps the best-known examples being banking and confectionary (e.g. Emden 1940; King 2014; Raistrick 1951; Windsor 1980; Walvin 1997). There are a number of reasons why Quakers were disproportionately associated with successful businesses during this period, although the ethics of Quakers businesses has attracted a few critical voices (e.g. Rowlinson 1988, 1995; Rowlinson and Hassard 1993; Sahle 2018). Nonetheless, Quakers are often associated with a reputation for honesty and integrity and their business ventures were often established with socio-economic ambitions (Burton et al. 2019), drawing upon religious principles and ethics (Fincham 2017). Quakers were well-known for their hard work which was successfully leveraged through strong bonds of kinship, dense industrial networks of co-religionists (Burton and Turnbull 2019) and continuous innovation in organisation and management (Maclean et al. 2020). In this section we attempt to place Quaker business ethics within MacIntyre's broad concept of traditions before going on to suggest that there is an important affinity between Quaker business ethics and MacIntyre's own preferred tradition of ethical thought in the following sections.

According to MacIntyre, a tradition is.

an argument extended through time in which certain fundamental agreements are defined and redefined in terms of two kinds of conflict: those with critics and enemies external to the tradition who reject all or at least key parts of those fundamental agreements, and those internal, interpretative debates through which the meaning and rationale of the fundamental agreements come to be expressed and whose progress a tradition is constituted (MacIntyre 1988, p. 12).

This contrasts both with a conception of inquiry that seeks some tradition-transcendent Archimedean point, and with a more general relativistic scepticism about truth-positions MacIntyre characterises as 'Encyclopaedia' and 'Genealogy' respectively (MacIntyre 1990). We must always begin from a highly particular set of premises and assumptions, and with a particular understanding of how to proceed intellectually. As such, MacIntyre defends.

a conception of rational enquiry as embodied in a tradition, a conception according to which the standards of rational justification themselves emerge from and are part of a history in which they are vindicated by the way in which they transcend the limitations of and provide remedies for the defects of their predecessors within the history of that same tradition (MacIntyre 1988, p. 7).

While some have seen in this conception of rational enquiry a defence of relativism (a charge rebutted by Lutz 2004, Kuna 2005, and Seipel 2015), the ramifications, in the context of organisational research and business ethics, is that the "traditional approach to enquiry holds to a notion of truth that seeks neither the timelessness of law-like generalizations nor the dissolution of categories through which enquiry is undertaken" (Beadle and Moore 2006, p. 326).

This conception of rational enquiry thus has an important affinity with the Quaker notion of 'experimental' knowing. According to this concept, claims to knowledge are based on experience that arises from right action, and they serve in turn as the basis for further 'experiments' (Muers 2015, p. 15 ) and thus form part of a continuing process, and indeed a continuing tradition. This also accords with the notion that the spiritual journey of the Quaker is continuous, and unending, just as MacIntyre describes "the good life for man is the life spent in seeking for the good life for man" (MacIntyre 2007, p. 219. See also Moore 2005, pp. 245-247).

This conception of a spiritual journey arises in part from Quaker discernment, a notion with connotations of spiritual clarity (Miller 2020), rather than intellectual judgement (Miller 2020), and thus is one of the distinctive epistemic features of the Quaker tradition. Its centrality to Quakerism means that it is key to understanding Quaker ethics and business practice. Discernment is grounded in the idea of the Light Within implanted by God in every person and a readiness to answer that of God in another (Dandelion 2004). Quakers widely reject the sacred/secular binary, have no priesthood or other formalised hierarchy, and Quakers afford 
primacy to the personal and social experience, rather than creed or scripture; for Quakers, knowing truth and living truth are inseparable (Muers and Burton 2019). It proceeds with a process of 'centring down', an entry into silence and inward reflection that encourages community connection. Periods of silence and spoken contributions are interwoven as individuals open up their own individual knowledge and beliefs to others in the group and self-reflexively examine their own judgement in light of the contribution of others with an aim to foster a wider group-wisdom and collective unity. It is interesting to observe that Quakers embed the virtue of humility in the idea "Think it possible you may be mistaken" (Quakers in Britain 1995, 13.10) in order to effect a qualitative change in individual beliefs and knowledge, and a willingness to sense the emerging unity of the group (Anderson 2006). Quaker discernment, therefore, recognizes that members of a group have "different experience, different kinds of knowledge" (Ambler 2013, p. 69) that help shape individual knowledge and belief into a collective unity that reflects the 'sense of the meeting' (Allen 2017). The continuous and evolving cycle of discernment and social action to which Muers refers shows how Quakers eschew epistemic closure and engage in morally reflexive cycles of discernment and social action that come to reflect a constantly evolving tradition (Vu and Burton 2020).

Like other religious traditions, Quakerism is characterised by a distinctive set of ethical and moral concerns. In the Quaker tradition, these are embedded in the Quaker testimonies to peace, truth, integrity, simplicity, and equality (Quakers in Britain 1995). Revised once every generation, the Quaker testimonies represent "storied and shared traditions of practice" (Burton et al. 2018, p. 360) that interact with discernment in multiple ways. For example, Quaker testimonies shape how Quakers discern between right and wrong action, and yet the testimonies are guided and shaped by continuing discernment across both time and space as an evolving process-what Quakers call continuing revelation (Anderson 2007).

This reveals the distinctive epistemic standards of the Quaker tradition. MacIntyre says "all reasoning takes place within the context of some traditional mode of thought, transcending through criticism and invention the limitations of what had hitherto been reasoned in that tradition" (MacIntyre 2007, p. 222), but another distinctive feature of the Quaker tradition is that it departs from this more adversarial model of intellectual and spiritual progress. While the basic features of a tradition are present, and indeed are hard to depart from entirely (see Lutz 2004, p. 56), Quakerism seems, in part, to be defined as a tradition that seeks to emphasise unity as well as the worthiness and equality of all contributions. While there is a great degree of plurality in Quaker thought (for a discussion, see Dandelion 2004, 2008), there is nevertheless a distinction between Quaker practices and practices which would not fit with the precepts and values of Quakerism. Dandelion (2004) has called this the behavioural creed of Quaker practice. Moreover, Quakers' emphasis on unity is only explicable in the context of a separation from contrasting practices in both business and theology. By positioning itself in a way that emphasises unity, Quakerism tacitly critiques the adversarial approaches of other traditions in a way that could not be voiced in terms of philosophical objections in a debate between opponents i.e. in the manner that MacIntyre regards as central to the debates between rival traditions. Thus, we continue to see epistemic humility as a central virtue of the Quaker tradition.

This humility is reflected in the recognition that a Quaker's spiritual journey, which discernment encourages, is never complete and so is unending. Rather, Quakers acknowledge that self-transformation is an ethically salient process, itself valuable and inseparable from its desired outcome. The silence that frames Quaker discernment enables communication "with God and the "self"” (Fennell 2012, p. 555), is the starting point of this process, and encourages a reconstructed "personhood" (Smolenski 1999) that is itself open to further transformations in the future. This journey is a shared journey. As MacIntyre says of traditions, "whoever we are, we can only begin enquiry from the vantage point afforded by our relationship to some specific social and intellectual past through which we have affiliated ourselves to some particular tradition of enquiry, extending the history of that enquiry into the present" (MacIntyre 1988, p. 401). This connects to the emphasis in Quakerism of the importance of discernment, of reaching a shared understanding of the sense of the meeting, and thus to the concept of community, which is the topic of the following section.

These Quaker practices have given rise to a distinctive method in business. While discernment emphasises unity, it is nevertheless difficult to adequately make sense of it outside of the theological context of the Quaker tradition (Muers and Burton 2019). Hence it is not feasible to simply amalgamate Quaker discernment with practices from other traditions even where there are important similarities, such as in the case of Buddhism (Vu and Burton 2020). In line with MacIntyre's understanding of traditions, an attempt to take a 'pick and mix' of practices outside the wider traditional context is to be apt to misunderstand, and thus misapply, them.

There are any number of traditions in the broad sense. Buddhism, Marxism, and even Liberalism, despite its self-understanding as neutral and a-traditional, are to be accounted traditions in this sense. However, there is also a more exclusive sense of 'tradition' that marks out the Thomistic-Aristotelian tradition, to which MacIntyre's own mature work is a contribution. This is the Tradition that is contrasted with Genealogy and Encyclopaedia in Three Rival Versions of Moral Enquiry (MacIntyre 1990), and includes Plato, 
Aristotle, Augustine, and Aquinas among its central contributors. While Quakerism is clearly a tradition is the broad categorical sense, it also can be understood as neighbouring this distinctly MacIntyrean tradition (a term we prefer due to the differences between Thomism and Quaker theology). This ethical proximity is particularly evident when we examine the affinities between Quaker business ethics and MacIntyrean business ethics. In what follows, we explore three key areas where this similarity is most evident, beginning with the concept of community.

\section{Community}

The concept of community is an essential feature of MacIntyre's work, and indeed many applications of his work in the business ethics literature have focussed on accounting some occupation a kind of practice-based community. While there has been much written on MacIntyre's concept of a practice, both within the business ethics literature (e.g. Moore 2002; Moore and Beadle 2006; Sinnicks 2019), and without (e.g. Miller 1984; Knight 2008; Hager 2011), in this section we focus on the broader conception of community itself, as we are concerned with the more general question of Quaker business ethics as a mode of engagement, than with the nature of particular forms of work.

In recent times, Quakers have directed their efforts towards such goods as peacebuilding, humanitarian work, and economic reform (Muers 2015), building upon the tradition of Quakers in the nineteenth and early twentieth centuries who discerned a pressing social purpose for business. Thus, the Quaker business tradition builds on a wider vision than that of simply achieving business success. Indeed, this wider ethical vision is expressed in the way Quaker businesses have typically sought to serve wider communities, such as "their workers, factories, towns and cities" (Turnbull 2014, p. 60).

As we have noted, Quaker business practice is grounded in the idea of the Light Within implanted by God in every person and a readiness to answer that of God in another (Dandelion 2004). This reflects a commitment to equality that is also manifest in, among other things, an acceptance of the equality of voices in discernment. As Quakers have no formal hierarchy, discernment is not led by any one person by virtue of their power or position. Rather, Quakers nominate a clerk, for a period of no more than three years, whose role is to stand outside the discernment process in order to more-effectively sense the emerging unity and capture that sense contemporaneously in a minute (the action agreed by those present). Thus, the clerk has no formal power as traditionally understood, but rather acts as a servant of the meeting (see Beaver 2014; Crippen 2011; Greenleaf et al. 1996 for Quaker roots in servant leadership).
This accords with MacIntyre's claim that "insofar as human beings have the capacity to become good, they also have the capacity to exercise the prudence of a ruler" (MacIntyre 1996, p. 68). This insight helps with an account of business ethics that draws on MacIntyre to remain wary of undue deference to those who occupy positions of power (Sinnicks 2020a), an insight which has clear affinities with Quaker thought. While Quaker theology is varied (Dandelion 2014), at its heart is the notion that each one of us has a Light within (Rediehs 2016). Indeed, this openness to the fundamental equality of all humanity is partly why Quaker theology is so varied. MacIntyre notes that "a plain person who begins to understand her or his life as an uneven progress towards the achievement of her or his good is thus to some significant extent transformed into a moral philosopher" (MacIntyre 1992 p. 4). There is nothing categorically distinct or uniquely authoritative about the pronouncements of moral philosophy as a professionalised activity, a suspicion which finds a parallel in Quakerism's lack of a distinct priesthood, but rather a reflectiveness about and concern with the various goods required to flourish, ethically and spiritually, are important and available to all.

This egalitarian ethos is at odds with any perspective which affords authority to any individual or set of individuals, and again finds a parallel in MacIntyre's thought. According to MacIntyre "those who arrogate to themselves an exclusive, professionalised authority of a certain kind by that very act of arrogation discredit their own claims to legitimate authority" (MacIntyre 1996, p. 70). Here again we see grounds for a commitment to the epistemic humility we noted above was a feature of the Quaker tradition. These egalitarian and communal commitments have ramifications for Quaker business ethics. The practice of Quaker discernment offers opportunities for groups and teams to make responsible decisions within the workplace that attend to the ethical and/or spiritual values guiding the group. The practice of discernment encourages decisions which are "respectful, non-hierarchal, and ego-constrained manner, aiming to achieve unity around the way forward" ( $\mathrm{Vu}$ and Burton 2020, p. 220). This again has important affinities with MacIntyre's conception of community.

Sinnicks (2014) suggests that MacIntyre's political thought is key to any successful attempt to apply MacIntyre to business ethics, and Bernacchio (2018) focuses on inter-organisational networks in a way that emphasises a shared sense of community which underpins the Aristotelian conception of politics. In this vein, MacIntyre specifies certain necessary conditions for a political or social institution to be conducive to the achievement of individual and common goods. He says: "They must afford expression to the political decision-making of independent reasoners on all those matters on which it is important that the members 
of a particular community be able to come through shared rational deliberation to a common mind" (MacIntyre 1999a, p. 129). This notion of shared decision-making has been drawn on in MacIntyrean business ethics (e.g. Bernacchio and Couch 2015) and, as we have noted, is a central feature of Quaker business ethics.

However, for Quaker business ethics, not just any form of shared decision-making will suffice. Quaker discernment is fundamentally different to reaching consensus (Anderson 2006). Rather than horse-trading or effecting a quantitative change in the beliefs of a group, reaching unity through discernment requires a qualitative change in individual beliefs and knowledge, and a willingness to sense the emerging unity even if that unity does not accord with an individuallyheld opinion or belief. Burton (2017) has described this type of discernment as the 'Quaker Business Method' (see also Bradney and Cownie 2000; Reis-Louis 1994). This method embeds Quaker theology, and reflects a distinctively collaborative approach to recognise that everyone is equally capable of contributing to the decision at hand. One of the notable features of Quaker discernment, therefore, is the absence of voting, which ostensibly is a marker of shared decision-making. Again, MacIntyre's reflections on politics can inform us as to why voting is not necessarily an indicator of adequate, communal decision-making. MacIntyre critiques contemporary society as being characterised by irresolvable ethical conflicts that leads to moral discourage becoming increasingly shrill (see MacIntyre 2007, especially chap. 1), and this means that contemporary political elections amounting to little more than the summing of untutored-or worse, artificial and manipulated-preferences, rather than a reflection of rational persuasion or shared deliberation. For MacIntyre, communities "must afford expression to the political decision-making of independent reasoners on all those matters on which it is important that the members of a particular community be able to come through shared rational deliberation to a common mind" (MacIntyre 1999a, p. 129). Likewise, Quakers seek to involve everyone, but in line with an opposition to adversarial or agonistic approaches as we noted above. Thus, the Quaker approach is characterised by an absence of confrontational debate and indeed of any method that emphasises differences of opinion. Instead, the Quaker method relies on a deliberate search for unity. Differences of opinion do, however, sometimes occur, and Quakers are adept at reflexively looking inward to understand and resolve difference and conflict. Where unity is not reached, this is not seen as 'failure', but rather that God's will could not be discerned at that time, and participants are invited to 'wait' and reconvene after a period of inward reflection.

Despite the absence of confrontation, discernment, however, cannot be described as sterile or conservative. Indeed, Quakers are called to 'Live Adventurously' and be prepared for discernment to open up new and unexpected insights
(Quakers in Britain 1995, 1.02). For example, Muers and Burton (2019) noted how, in 2009, Quakers approved the solemnisation of marriages for same-sex couples (before this was legal in the UK) highlighting the rapid movement from controversy to unity. In business, Quaker firms in the nineteenth and early twentieth century discerned the need for business to attend to social disadvantage and injustice and provided employee welfare benefits, pension schemes, and subsidised housing for employees (e.g. Walvin 1997) at a time when these kinds of social initiatives were uncommon.

In fact, many Quaker and Quaker-connected organisations continue to embed discernment as an explicit approach to decision-making in their constitution. For example, the Scott Bader Commonwealth-a medium-sized, international chemical manufacturing company-was established by a Quaker family in 1921 as a limited company, and converted to employee ownership in 1951 as a commonwealth. Today, its constitution continues to refer to "decision-making by unity...rather than a formal vote" (Scott Bader Commonwealth, 2010, p. 27). Further, in the charity sector the Joseph Rowntree Charitable Trust describes its decision-making as "based on Quaker values...each Trust meeting starts and ends with a period of silent worship. We don't vote-we try to listen to each other and to God, so that we are guided to the right decision" (JRCT, n.d.).

It should be recognised, however, that ensuring all voices are heard in decision-making is especially challenging in business contexts, and not all Quaker businesses embedded the 'voice of labour'. For example, in the first-half of the twentieth century, Quaker firms held four Quaker Employer Conferences to discuss issues of the day including the voice and claims of labour, and which were followed by The Rowntree Lecture Series that bought together employers and employees from different levels of an organisations' hierarchy to confront pressing issues in British industry (Maclean et al. 2020). However, while Quaker firms embraced issues such as trade union membership, profit-sharing, and works' councils (Child 1964; Kimberley 2019), the voice of labour was often heard on the Quaker firms' own terms, and cooperative and common forms of ownership that widely shared power and decision-making were often dismissed or resisted due to concerns over future profitability of the enterprises. As Maclean et al. (2020, p. 11) noted, it is possible that Quakerism reinforced "a particular form of capitalism" that encouraged "employee compliance with managerial authority...through the validation of a managerial elite as the rightful guardians of administrative control if it could prove itself sufficiently humanist and caring of its workers" (Maclean et al. 2020, pp. 11-15). 


\section{Compartmentalisation}

According to MacIntyre, "The characteristic modern self is in various and varying ways a divided self" (MacIntyre 2008 p. 267). This division is a result of various pressures to compartmentalise the various roles we occupy. The effect of this compartmentalisation is that individuals focus only on particular roles at particular times, never achieving a roletranscendent perspective that would allow them to better order their concerns and priorities. Because of this compartmentalisation "there is a lessening of inner conflict, but at the cost of a lack of self-awareness. And this lack of selfawareness obscures the underlying unity of the divided self" (ibid). In other words, compartmentalisation reduces inner conflict because it makes the underlying incompatibility of values that inform our different roles invisible. Thus, we experience our different roles as if there were no conflict between them, when in fact there may well be deep, perhaps irresolvable, conflicts that remain necessarily hidden from view.

This compartmentalisation is especially likely to arise in the context of work, where there is a greater incentive to separate one's personal concerns and convictions from the values presupposed by or latent in one's occupational role. When describing Goodpaster and Sayre's (1977) study of the commitments of power company executives, MacIntyre says,

One incidental discovery... was that power company executives tended to a significant degree to answer what were substantially the same questions somewhat differently, depending on whether they took themselves to be responding qua power company executive or qua parent and head of household or qua concerned citizen. That is to say, their attitudes varied with their social roles and they seemed quite unaware of this (MacIntyre 1999b, pp. 321-322).

What this shows is that people are liable to meet the demands of the role they happen to play and where they have no standpoint from which to assess their whole lives, such contradictions may pass unnoticed. This compartmentalisation is ethically troubling in at least three related ways. Firstly, the inability to adjudicate between competing demands leaves one liable to prioritise a relatively trivial ethical demand, such as those to do with workplace performance, for instance, over more important demands such as those of being a good parent or citizen, for instance.

Secondly, it can undermine the development of virtues by allowing only for the development of context-specific skills. As MacIntyre says,

What are spoken of as the virtues of a good committee man or of a good gambler or a pool hustler are professional skills professionally deployed in those situa- tions where they can be effective, not virtues. Someone who genuinely possesses a virtue can be expected to manifest it in very different types of situation, many of them situations where the practice of a virtue cannot be expected to be effective in the way we can expect a professional skill to be (MacIntyre 2007, p. 205).

If the different types of situation we face are compartmentalised from each other, this cross-context application of the virtues becomes both intrinsically more difficult, and makes an education in the virtues less likely, as we become unable to ask ourselves whether we have been truly honest or truly kind if we are unable to transcend compartmentalised roles. Because "virtues, unlike skills, direct us only to good ends" (MacIntyre 2006, p. 117) this is a matter of serious concern as it again makes it harder for us to discern which ends are worthwhile.

Thirdly, it undermines the development of the key virtues of integrity and constancy in particular. The divided self, according to MacIntyre,

cannot have integrity, just because its allegiance to this or that set of standards is always temporary and context-bound. And it cannot have the constancy that is expressed in an unwavering directedness, since it recurrently changes direction, as it moves from sphere to sphere. Indeed its conception of a virtue will generally be one of excellence in role performance rather than of excellence as a human being and hence what is judged excellent in one role-governed context may be very different from and even sometimes incompatible with what is judged excellent in others (MacIntyre 1999b, pp. 324-325).

Thus, there is a special importance attached to maintaining a unity of concerns and commitments across different domains. This is reflected in the Quaker view that the dichotomy between the sacred and the secular is false. Instead, they see the divine as being present in both 'worldly' and 'religious' activity. This finds a parallel in MacIntyre's reflections on work. MacIntyre suggests that "there is a close connection between being a good human being and doing good work", a connection which "has been lost sight of altogether in the contemporary workplace" (MacIntyre 2011, p. 323). Here MacIntyre also says that when in good order work should be "thought of as a kind of prayer and performed as an act of prayer" (ibid). Echoing this view, Delbecq et al. (2004) remarked that 'mundane' activitiessuch as work-are always imbued with spiritual significance in carrying out God's work.

Not everyone is perhaps lucky enough to be employed in an organisation that adopts Quaker commitments to equality and unity, and so Quakers may find themselves just as subject to the pressures to compartmentalise as non-Quakers. 
Furthermore, Quakers are not infallible, and so may not always be able to resist this compartmentalisation, and so are not immune to the moral dissonance that compartmentalization can create for individuals in business and professional life (Burton and Vu 2020). Nevertheless, despite not being impervious to these pressures, the Quaker tradition is well-placed to both recognise them as problematic, and to resist them. For Quakers, the continuity of inner and outer life is deeply important, and the commitment to integrity can act as a safeguard against the kind of radical compartmentalisation that MacIntyre diagnoses as a central affliction of modernity. Raistrick, for example, commented that "their refusal to separate business activities from the principles and disciplines which regulated their religious life, gave them a stability and soundness of practice that was unusual in their day" (Raistrick 1951, p. 46).

Over history, a number of scholars have shown how Quakers, sometimes at high personal cost, have sought to resist compartmentalization. For example, early Quaker history has many examples of prominent Quaker businesspeople being jailed for refusing to swear an oath or remove a hat in court, signalling an unwavering commitment to Truth and Equality in all circumstances. Lloyd (2013), for example, narrated how the members of the Lloyds family (of the banking dynasty) were jailed for refusing to swear an oath, despite their significant business interests. Further, as Quaker enterprises grew and expanded, many Quaker firms needed external expertise unavailable within the community and invited non-Quakers to join the board. As this process continued, Quaker representation on the board diminished until they eventually lost control of and resigned from the businesses they had created e.g. Huntley and Palmer (Burton et al. 2019), Albright and Wilson (Sleapwood 2019) and Friends Provident (Tregoning and Cockerell 1982). In a similar way, as many Quaker businesses grew, the second, third and subsequent generations of Quaker families were often seduced by wealth from their parents' and grandparents' business ventures and often renounced Quakerism in order to pursue less 'plain' lives. Clearly Quakers are not immune to the corrupting power of what MacIntyre calls "external goods" (MacIntyre 2007, p. 190). As Burton et al. (2019) remarked in their case analysis of Huntley and Palmer, eventually there were too few second and third generation Quakers left to run the firms.

\section{Critique of Manipulative Management}

The final feature of MacIntyre's thought that we consider here is his critique of manipulative management. While compartmentalisation is a widespread danger in the contemporary workplace, it is especially likely to arise for the manager, according to MacIntyre. This is because the manager is such a "dominant figure on the contemporary scene" (MacIntyre 2007, p. 74) and represents a distinctive and aspirational model. MacIntyre refers to the manager as a distinctive 'character' in the drama of contemporary life. These characters "are a very special type of social role which places a certain kind of moral constraint on the personality of those who inhabit them in a way in which many other social roles do not" (MacIntyre 2007, p. 27), and thus the occupant of the managerial role is under a greater degree of pressure to compartmentalise than are members of other occupations. What is especially distinctive about the "character' of the manager, according to MacIntyre, is the way its reliance on instrumental rationality inevitably leads it to become manipulative. As MacIntyre puts it, the manager.

represents in his character the obliteration of the distinction between manipulative and non-manipulative social relations... The manager treats ends as given, as outside his scope; his concern is with technique, with effectiveness in transforming raw materials into final products, unskilled labor into skilled labor, investment into profits (MacIntyre 2007, p. 30).

In this way, management is an embodiment of emotivism, sometimes known as the 'boo-hurrah' theory of morality. Emotivism regards expressions of moral judgements as mere expressions of preference. As such, emotivism is a doctrine which "entails the obliteration of any genuine distinction between manipulative and non-manipulative social relations... others are always means, never ends" (MacIntyre 2007, pp. 23-24). Because moral judgements are mere expressions of preference, they cannot properly be part of any attempt to rationally persuade. They can, nevertheless, be used in attempts to change the views and actions of others but, in light of this non-rational nature, such attempts, where successful, are typically examples of manipulation.

This conception of value judgements, and the fact that ends are beyond the scope of managerial decision-making, leads to a fundamental distinction between those qualified to manage an organisation or rule a polity, and those managed or ruled, and thus falls foul of MacIntyre's political thought we touched on above. As Knight puts it.

To divide society between the knowing and the known, the managers and the managed, is to demoralize everyone. It is to deny the managed the agency that is necessary to engage in the social activity of changing from how one is to how one ought to be, and it is to exempt managers from any need for such improvement (Knight 2017, p. 82).

Those who have drawn on MacIntyre's work in business ethics typically hold that MacIntyre misrepresents the nature of management. Moore (2008), for example, attempts to use MacIntyre's arguments against him to 
present a more ethically affirmative conception of management. Moore (2017) also outlines a variety of characteristics of good management (pp. 110-114) and good organisations (pp. 124-130). MacIntyre restricts his critique to rational, bureaucratic management, perhaps due to its cultural dominance in the period leading up to the publication of After Virtue in 1981, and so perhaps ignores more ethically ameliorative forms of management. However, the charge of manipulativeness can be applied to various other models of management, and even to leadership, including value-laden forms such as charismatic and transformational leadership (Sinnicks 2018). So, while MacIntyre's work has had a significant impact in business ethics, there is some truth to the charge that his work has been misappropriated by those with more favourable views of contemporary capitalism and the modern workplace (Beadle 2002). In any case, our concern in the remainder of this section is to argue that Quaker business ethics shares MacIntyre's ethical opposition to narrow self-interest and acquisitiveness, as well as to this critique of emotivistic and manipulative management.

For sure, the Quaker approach to business ethics in the nineteenth and early twentieth centuries had a different social, political, and economic context, and so it may be unwise to draw lessons about particular practices and policies too readily. Indeed, there are examples of unethical or, at the very least, surprising practices that it is important to recount. For example, Wagner-Tsukamoto (2008) argued that most of the welfare advances in Quaker firms were only introduced once they had been 'tested' by Quaker employers in economic terms and if economic benefits did not exist, welfare programmes were abandoned. Rowlinson (1988) noted the implementation of a form of scientific management at Cadbury's in the early twentieth century, and argued that this could hardly be characterised as an embodiment of Quaker values. Corley (1972) noted likewise at Huntley and Palmer. Later, Rowlinson and Hassard (1993) described Cadbury's corporate culture as "invented". Through their purchase of cocoa in the West Indies, Rowntrees had links to slavery and indentured labour (Fitzgerald 1995; Robertson 2009). Finally, Smith (1967) recounts an example of the Galton family in Birmingham engaged in making guns and armaments. Such practices are at odds with wider Quaker commitments.

Nevertheless, the broader set of values that underpinned Quaker business in this period remains instructive. For Quakers, work was not simply a matter of wealth creation. Rather, wealth creation assumed a moral significance (Walvin 1997) that showed "truth to the world" (Raistrick 1951, p. 46). Many Quakers recognised the link between business profitability and the ability to provide employee welfare. This is connected to ideals of service to society that animate recent applications of MacIntyre's thought to finance (see, for instance, Sison et al. 2019; Rocchi et al. 2021), as well as the notion of stewardship that Potts (2020) argues is central to good management. Although Quaker businesses have since been accused of paternalism (e.g. Turnbull 2014), they belonged to a social tradition of industrial philanthropy which included industrialists of many faiths (and none) in the Victorian era who regarded its employees as part of an extended family. This conception is deeply at odds with an approach to management that treats employees merely as means to the pre-set end of profit.

There are a number of examples from Quaker business practice during this period that illustrate such a concern with employee and community welfare. Joseph Rowntree developed a Works Magazine and Works library in 1902. Cadbury's developed a sick club to care for, and provide wages to, staff who were ill and unable to work. Many Quaker employers introduced works councils, profit share schemes, free dental care, and half-day and bank holidays (Burton and Hope 2018; Bradley 1987). Notably, both the Rowntree and Cadbury families provided a pension scheme just after the turn of the twentieth century (Walvin 1997), and the Quaker model villages at Bourneville, Birmingham, and New Earswick, York, are perhaps the best-known expression of their social vision. These initiatives suggest that Quaker businesses recognised the worth of workers beyond their contributions considered in narrow economic terms, and mirror Bernacchio's (2020) suggestion that the MacIntyrean perspective can ground a case for employee rights. Returning to the example of the Scott Bader Commonwealth, these kinds of these kinds of social concern that were initially exemplified by its Quaker founder continue to manifest in strong commitments to employee ownership and charitable aims (Scott Bader Commonwealth, n.d.)

Quakers also recognised a sense of their responsibilities to a wider vision for community and society, responsibilities which would beyond the scope of the emotivist character of the manager. Many prominent Quaker industrialists held roles in their local cities and communities. For example, Turnbull (2014) recounts how Richard Capper Cadbury and John Cadbury served as Overseers of the Poor in Birmingham. John Cadbury was also chairman of the Markets and Fairs Committee and a governor of Birmingham General Hospital. The Cadburys and Rowntrees were also closely involved in education and social justice. For example, Joseph Rowntree remains well-known for establishing a Quaker school in York and the creation of the New Earswick model village on the city outskirts, and the Joseph Rowntree trusts continue to use their foundation to advance social aims to this day (e.g. Freeman 2003; Davies and Freeman 2005).

We noted above that Quakers place a high value on equality and unity. Such goods are incompatible with the conception of management that MacIntyre targets with his critique. Moreover, the practice of discernment, perhaps the key 
feature of a distinctly Quaker business practice, is incompatible with regarding others as mere cogs in the machine of the business organisation. As such, Quaker business ethics is incompatible with the kind of manipulative social relations that MacIntyre regards, rightly or wrongly, as endemic in contemporary capitalism.

Today, few Quaker-owned businesses remain, and the reasons for this are complex. While Quaker businesses, on the whole, were largely successful, how they came to disappear from the business landscape deserves comment. WagnerTsukamoto (2008) suggests that the Quaker business ethics ignored the market and that the market selected against them. Perhaps this assertion is too simplistic, though it is possible that it was advantageous to draw on the manipulative, emotivistic managerial approaches MacIntyre criticised at that time, which put the more ethical approaches adopted by Quakers at a disadvantage. Cadbury (2010) suggests that the emergence of the UK welfare state in the first-half of the twentieth century reduced the need for a charitable Quaker business. Burton et al. (2019) argue that the change from family partnerships to the shareholder economy in the second-half of the nineteenth century resulted in a weakening of Quaker firms' social ambitions as non-Quakers came to occupy prominent managerial positions as a consequence of mergers, acquisitions and other market mechanisms. MacIntyre's claim that the modern economic order "provides systematic incentives to develop a type of character that has a propensity to injustice" (MacIntyre 1995, p. xiv) suggests that it will be difficult for any ethical tradition to emerge entirely unscathed from an encounter with it. Quaker business ethics is clearly aligned with MacIntyre's critique of manipulative management, but the decline of Quaker business also serves to illustrate that the pressures of 19th and early twentieth century capitalism drove business in a direction that was especially compatible with that approach to management. That Quakers often experienced success in this realm presents a dilemma-leave business or leave the Quakers-is a testament to the strength of the Quaker ethical tradition in business and beyond.

\section{Conclusion}

In this paper we have attempted to provide an account of Quaker business ethics in MacIntyrean terms, with the aim of enhancing our understanding of both traditions. A comprehensive comparison between the two traditions would have to confront their dissimilarities. These stem both from the differences between Catholic and Quaker theology, as well as from MacIntyre's own hostility to capitalism (see Sinnicks 2020b for a discussion in the context of business ethics). Nevertheless, Quakerism shares a number of important affinities between with MacIntyre's ethical thought, and this connection is especially clear in the domain of business ethics. In this paper we have brought attention to three areas in which this connection is most visible: community, compartmentalisation, and a critique of manipulative management.

Sir Adrian Cadbury (foreword, King 2014) disputes whether a return to Quaker business ethics is possible in a shareholder economy. Our discussion in this paper points to some hope. Quakers have a long history of exploring alternative ways of organising - the Commonwealth structure of Scott Bader deployed originally in 1951 speaks to this-and the Quaker emphasis on non-hierarchal forms of organisation highlight the way in which Quakers see organisation and ethical practice as entwined. Renewed interest in the B-Corporation movement, common or co-operative ownership and employee ownership are gaining traction, perhaps in a way that replicates the Quaker concern of economic and social balance. In some ways, Quaker business ethics can be understood as having been partially and tacitly integrated into modern capitalism through widespread interest in CSR and responsible business even if the Quaker businesses themselves no longer exist as they once did. However, divorced from the deeper ethical commitments of Quakerism, these practices are inherently more liable to depart from the sense of community, and the resistance to compartmentalization and manipulation that are so important to business ethics in the Quaker tradition and the MacIntyrean tradition.

Acknowledgements We would like to thank handling editor Alejo José G. Sison, and two anonymous reviewers for JBE for comments on earlier versions of this paper.

\section{Compliance with Ethical Standards}

Conflict of Interest The authors declare that they have no conflict of interest.

Ethical Approval This article does not contain any studies with human participants or animals performed by any of the authors.

Open Access This article is licensed under a Creative Commons Attribution 4.0 International License, which permits use, sharing, adaptation, distribution and reproduction in any medium or format, as long as you give appropriate credit to the original author(s) and the source, provide a link to the Creative Commons licence, and indicate if changes were made. The images or other third party material in this article are included in the article's Creative Commons licence, unless indicated otherwise in a credit line to the material. If material is not included in the article's Creative Commons licence and your intended use is not permitted by statutory regulation or exceeds the permitted use, you will need to obtain permission directly from the copyright holder. To view a copy of this licence, visit http://creativecommons.org/licenses/by/4.0/. 


\section{References}

Allen, S. (2017). Learning from friends: Developing appreciations for unknowing in reflexive practice. Management Learning, 48(2), $125-139$.

Ambler, R. (2013). The Quaker way: A rediscovery. Hampshire, UK: John Hunt Publishing.

Anderson, P. (2006). The meeting for worship in which business is conducted: Quaker decision-making process as a factor of spiritual discernment. Quaker Religious Thought, 106(1), 26-47.

Anderson, P. (2007). Continuing revelation-gospel or heresy? In J. L. Scully \& P. Dandelion (Eds.), Good and evil: Quaker perspectives (pp. 15-29). Hampshire: Ashgate/Gower.

Beadle, R. (2002). The misappropriation of MacIntyre. Philosophy of Management, 2(2), 45-54.

Beadle, R. (2017). MacIntyre's influence on business ethics. In A. J. G. Sison, G. R. Beabout, \& I. Ferrero (Eds.), Handbook of virtue ethics in business and management (pp. 59-67). Dordrecht: Springer.

Beadle, R., \& Moore, G. (2006). MacIntyre on virtue and organization. Organization Studies, 27(3), 323-340.

Beaver, T. L. (2014). Historical derivative of servant leadership and the untold story of the influence of Quakerism on Greenleaf's teachings. In R. Selladurai (Ed.), Servant Leadership: Research and practice (pp. 244-261). Hershey: IGI Global.

Bernacchio, C. (2018). Networks of giving and receiving in an organizational context: Dependent rational animals and MacIntyrean business ethics. Business Ethics Quarterly, 28(4), 377-400.

Bernacchio, C. (2019). Pope Francis on conscience, gradualness, and discernment: Adapting Amoris Laetitia for business ethics. Business Ethics Quarterly, 29(4), 437-460.

Bernacchio, C. (2020). Virtue beyond contract: A MacIntyrean approach to employee rights. Journal of Business Ethics. https ://doi.org/10.1007/s10551-020-04435-2.

Bernacchio, C., \& Couch, R. (2015). The virtue of participatory governance: A MacIntyrean alternative to shareholder maximisation. Business Ethics: A European Review, 24(S2), S130-S143.

Burton, N. (2017). Quaker business method: A contemporary decision-making process? In S. Angell \& P. Dandelion (Eds.), Quakers, business and industry (pp. 242-262). Philedelphia: Friends Association in Higher Education.

Burton, N., \& Hope, A. (2018). Responsibility in business: What can we learn from the Quakers? In M. Snarr \& D. Ross (Eds.), Quakers, politics and economics. Philedelphia: Friends Association in Higher Education.

Burton, N., Kavanagh, D., \& Brigham, M. (2019). Religion, organization and company law: A case study of a Quaker business. Management and Organizational History, 14(4), 317-336.

Burton, N., Koning, J., \& Muers, R. (2018). Organizational ethnography and religious organizations: The case of Quaker decisionmaking. Journal of Management, Spirituality and Religion, 15(4), 349-367.

Burton, N., \& Turnbull, R. (2019). Quakers, business and corporate responsibility. Cham: Springer.

Burton, N., \& Vu, M. C. (2020). Moral identity and the Quaker tradition: Moral dissonance negotiation in the workplace. Journal of Business Ethics. https://doi.org/10.1007/s10551-020-04531 -3 .

Bradley, I. C. (1987). Enlightened entrepreneurs. London: Weidenfeld and Nicolson.

Bradney, A., \& Cownie, F. (2000). Living without law: An ethnography of Quaker decision-making, dispute avoidance, and dispute resolution. Aldershot: Ashgate Publishing.

Cadbury, D. (2010). Chocolate wars: From Cadbury to Kraft: 200 years of sweet success and bitter rivalry. London: HarperCollins.
Child, J. (1964). Quaker employers and industrial relations. The Sociological Review, 12(3), 293-315.

Chu, I., \& Moore, G. (2020). From harmony to conflict: MacIntyrean virtue ethics in a confucian tradition. Journal of Business Ethics, 165(2), 221-239.

Corley, T. A. B. (1972). Quaker enterprise in biscuits: Huntley and Palmers of reading, 1822-1972. London: Hutchinson Radius.

Crippen, C. (2011). Greenleaf's servant-leadership and Quakerism: A nexus. International Journal of Servant-Leadership, 6(1), 199-211.

Dandelion, P. (2004). Research note. Implicit conservatism in liberal religion: British Quakers as an 'uncertain sect.' Journal of Contemporary Religion, 19(2), 219-229.

Dandelion, P. (2008). The Quakers: A very short introduction. Oxford: Oxford University Press.

Dandelion, P. (2014). The British Quaker Survey 2013. Quaker Religious Thought, 123(1), 15.

Davies, J., \& Freeman, M. (2005). A case of political philanthropy: The Rowntree family and the campaign for democratic reform. Quaker Studies, 9(1), 95-113.

Delbecq, A., Liebert, E., Mostyn, L., Nutt, P., \& Walter, G. (2004). Discernment and strategic decision-making: Reflections for a spirituality of organizational leadership. In M. L. Pava (Ed.), Spiritual intelligence at work: Meaning, metaphor and morals (pp. 139-174). San Francisco: Elsiver.

Emden, P. (1940). Quakers in commerce: a record of business achievement. London: S. Low, Marston and Company Limited.

Fennell, D. (2012). Explorations of silence in the religious rituals of Buddhists and Quakers. Religion, 42(4), 549-574.

Ferrero, I., \& Sison, A. J. G. (2014). A quantitative analysis of authors, schools and themes in virtue ethics articles in business ethics and management journals (1980-2011). Business Ethics: A European Review, 23(4), 375-400.

Fincham, A. (2017). Factors supporting the rise of Quaker commerce. In S. Angell \& P. Dandelion (Eds.), Quakers, business and industry (pp. 6-33). Philadelphia: Friends Association in Higher Education.

Fitzgerald, R. (1995). Rowntree and the marketing revolution, 1862 1969. Cambridge: Cambridge University Press.

Freeman, M. (2003). Victorian philanthropy and the Rowntrees: The Joseph Rowntree Charitable Trust. Quaker Studies, 7(2), 193-213.

Goodpaster, K., \& Sayre, K. (1977). An ethical analysis of power company decision-making. In K. Sayre (Ed.), Values in the electric power industry. Notre Dame, IN: University of Notre Dame Press.

Greenleaf, R. K., Fraker, A. T., \& Spears, L. C. (1996). Seeker and servant: Reflections on religious leadership. San Francisco: Jossey-Bass Inc Publishing.

Gould, S. J. (1995). The Buddhist perspective on business ethics: Experiential exercises for exploration and practice. Journal of Business Ethics, 14(1), 63-70.

Hager, P. (2011). Refurbishing MacIntyre's account of practice. Journal of Philosophy of Education, 45(3), 545-561.

Joseph Rowntree Charitable Trust (n.d). "About Us". Retrieved from https://jrct.org.uk/about-us. Accessed 23 Sept 2020.

Kimberley, J. (2019). Employee relations and the Quaker employers conference of 1918: The Cadbury Company. Quaker studies, 24(2), 229-248.

King, M. (2014). Quakernomics: An ethical capitalism. London: Anthem Press.

Knight, K. (2008). Practices: The Aristotelian concept. Analyse and Kritik, 30(1), 317-329.

Knight, K. (2017). MacIntyre's critique of management. In A. J. G. Sison, G. R. Beabout, \& I. Ferrero (Eds.), Handbook of virtue 
ethics in business and management (pp. 79-87). Dordrecht: Springer.

Koehn, D. (2001). Confucian trustworthiness and the practice of business in China. Business Ethics Quarterly, 11(3), 415-429.

Kuna, M. (2005). Macintyre on tradition, rationality, and relativism. Res Publica, 11(3), 251-273.

Lloyd, H. (2013). Quaker lloyds in the industrial revolution. London: Routledge.

Lutz, C. S. (2004). Tradition in the ethics of Alasdair MacIntyre: Relativism, thomism, and philosophy. Lanham, MD: Rowman and Littlefield.

MacIntyre, A. (1988). Whose justice? Which rationality? London: Duckworth.

MacIntyre, A. (1990). Three rival versions of moral enquiry: Encyclopaedia, genealogy, and tradition. London: Duckworth.

MacIntyre, A. (1992). Plain persons and moral philosophy. American Catholic Philosophical Quarterly, 66(1), 3-19.

MacIntyre, A. (1995). Christianity and marxism (2nd ed.). London: Duckworth.

MacIntyre, A. (1996). Natural law as subversive: The case of aquinas. Journal of Medieval and Early Modern Studies, 26(1), 61-83.

MacIntyre, A. (1999a). Dependent rational animals: Why human beings need the virtues. Chicago, IL: Open Court.

MacIntyre, A. (1999b). Social structures and their threats to moral agency. Philosophy, 74(3), 311-329.

MacIntyre, A. (2006). The tasks of philosophy: Selected essays (Vol. 1). Cambridge: Cambridge University Press.

MacIntyre, A. (2007). After virtue (3rd ed.). London: Duckworth.

MacIntyre, A. (2008). What more needs to be said? A beginning, although only a beginning, at saying it. Analyse and Kritik, 30(1), 261-281.

MacIntyre, A. (2011). Where we were, where we are, where we need to be. In P. Blackledge \& K. Knight (Eds.), Virtue and politics: Alasdair MacIntyre's revolutionary aristotelianism (pp. 307334). Notre Dame, IN: University of Notre Dame Press.

MacIntyre, A. (2016). Ethics in the conflicts of modernity. Cambridge: Cambridge University Press.

Maclean, M., Shaw, G., Harvey, C., \& Booth, A. (2020). Management learning in historical perspective: Rediscovering Rowntree and the British interwar management movement. Academy of Management Learning and Education, 19(1), 1-20.

McCann, D. P., \& Brownsberger, M. L. (1990). Management as a social practice: Rethinking business ethics after MacIntyre. The Annual of the Society of Christian Ethics, 10, 223-245.

Miller, D. (1984). Virtues and practices. Analyse and Kritik, 6(1), 49-60.

Miller, K. D. (2020). Discernment in management and organizations. Journal of Management, Spirituality and Religion. https://doi. org/10.1080/14766086.2020.1812425.

Moore, G. (2002). On the implications of the practice-institution distinction: MacIntyre and the application of modern virtue ethics to business. Business Ethics Quarterly, 12(1), 19-32.

Moore, G. (2005). Humanizing business: A modern virtue ethics approach. Business Ethics Quarterly, 15(2), 237-255.

Moore, G. (2008). Re-imagining the morality of management: A modern virtue ethics approach. Business Ethics Quarterly, 18(4), 483-511.

Moore, G. (2017). Virtue at work: Ethics for individuals, managers, and organizations. Oxford: Oxford University Press.

Moore, G., \& Beadle, R. (2006). In search of organizational virtue in business: Agents, goods, practices institutions and environments. Organization Studies, 27(3), 369-389.

Moore, G., Beadle, R., \& Rowlands, A. (2014). Catholic social teaching and the firm: Crowding in virtue: A MacIntyrean approach to business ethics. American Catholic Philosophical Quarterly, 88(4), 779-805.
Muers, R. (2015). Testimony: Quakerism and theological ethics. London: SCM Press.

Muers, R., \& Burton, N. (2019). Can we take the religion out of religious decision-making? The case of Quaker business method. Philosophy of Management, 18(3), 363-374.

Murphy, M. J., \& Smolarski, J. M. (2020). Religion and CSR: An Islamic "political" model of corporate governance. Business and Society, 59(5), 823-854.

Pace, S. (2013). Does religion affect the materialism of consumers? An empirical investigation of Buddhist ethics and the resistance of the self. Journal of Business Ethics, 112(1), 25-46.

Poruthiyil, P. V. (2020). Religious ethics: An antidote for religious nationalism. Business and Society, 59(5), 1035-1061.

Potts, G. (2020). The calling of the virtuous manager: Politics shepherded by practical wisdom. Business Ethics: A European Review, 29(S1), 6-16.

Quakers in Britain. (1995). Quaker faith and practice. London: The Yearly Meeting of Religious Society of Friends.

Raistrick, A. (1951). Quakers in science and industry. New York: Philosophical Library.

Rediehs, L. (2016). A distinctive Quaker theory of knowledge: An expanded experiential empiricism. Quaker Studies, 21(1), 67-94.

Reis-Louis, M. (1994). In the manner of friends: Learnings from Quaker practice for organizational renewal. Journal of Organizational Change Management, 7(1), 42-60.

Robertson, E. (2009). Chocolate, women and empire: A social and cultural history. Manchester: Manchester University Press.

Rocchi, M., Ferrero, I., \& Beadle, R. (2021). Can finance be a virtuous practice? A MacIntyrean account. Business Ethics Quarterly, 31(1), 75-105.

Romar, E. J. (2004). Globalization, ethics, and opportunism: A Confucian view of business relationships. Business Ethics Quarterly, 14(4), 663-678.

Rowlinson, M. (1988). The early application of scientific management by Cadbury. Business History, 30(4), 377-395.

Rowlinson, M. (1995). Strategy, structure and culture: Cadbury, divisionalization and merger in the 1960s. Journal of Management Studies, 32(2), 121-140.

Rowlinson, M., \& Hassard, J. (1993). The invention of corporate culture: A history of the histories of Cadbury. Human Relations, 46(3), 299-326.

Sahle, E. (2018). Quakers, coercion, and pre-modern growth: Why Friends' formal institutions for contract enforcement did not matter for early modern trade expansion. The Economic History Review, 71(2), 418-436.

Scott Bader Commonwealth (2010). Constitution. Retrieved from https://www.scottbader.com/uploads/files/4258_comms-book11 nov.pdf. Accessed 15 April 2020.

Scott Bader Commonwealth (n.d.) 2036 vision. Retrieved from https ://www.scottbader.com/ecology/our-philosophy/our-2036-visio n-and-goals/. Accessed 15 April 2020.

Seipel, P. (2015). In defense of the rationality of tradition. Canadian Journal of Philosophy, 45(3), 257-277.

Sidani, Y., \& Al Ariss, A. (2015). New conceptual foundations for Islamic business ethics: The contributions of Abu-Hamid AlGhazali. Journal of Business Ethics, 129(4), 847-857.

Sinnicks, M. (2014). Practices, governance, and politics: Applying MacIntyre's ethics to business. Business Ethics Quarterly, 24(2), 229-249.

Sinnicks, M. (2018). Leadership after virtue: MacIntyre's critique of management reconsidered. Journal of Business Ethics, 147(4), $735-746$

Sinnicks, M. (2019). Moral education at work: On the scope of MacIntyre's concept of a practice. Journal of Business Ethics, 159(1), 105-118. 
Sinnicks, M. (2020a). The just world fallacy as a challenge to the business-as-community thesis. Business and Society, 59(6), 1269-1292.

Sinnicks, M. (2020b). "We ought to eat in order to work, not vice versa": MacIntyre, practices, and the best work for humankind. Journal of Business Ethics. https://doi.org/10.1007/s1055 1-020-04603-4.

Sison, A. J. G., Ferrero, I., \& Guitián, G. (2016). Human dignity and the dignity of work: Insights from Catholic social teaching. Business Ethics Quarterly, 26(4), 503-528.

Sison, A. J. G., Ferrero, I., \& Guitián, G. (2019). Characterizing virtues in finance. Journal of Business Ethics, 155(4), 995-1007.

Sleapwood, N. (2019). Albright and Wilson and change in the Quaker business environment during World War I. Quaker Studies, 24(2), 189-210.

Smith, B. M. (1967). The Galtons of Birmingham: Quaker gun merchants and bankers, 1702-1831. Business History, 9(2), $132-150$.

Smolenski, J. (1999). As the discharge of my conscience to god": Narrative, personhood, and the construction of legal order in 17thcentury Quaker culture. Prospects, 24, 117-175.

Tregoning, D., \& Cockerell, H. A. L. (1982). Friends for life: Friends' provident life office, 1832-1982. London: H. Melland, for Friends' Provident Life Office.
Turnbull, R. (2014). Quaker capitalism: Lessons for today. Oxford: Centre for Enterprise, Markets and Ethics.

Velasquez, M., \& Brady, F. N. (1997). Natural law and business ethics. Business Ethics Quarterly, 7(2), 83-107.

Vu, M. C., \& Burton, N. (2020). Mindful reflexivity: Unpacking the process of transformative learning in mindfulness and discernment. Management Learning, 51(2), 207-226.

Wagner-Tsukamoto, S. (2008). Contrasting the behavioural business ethics approach and the institutional economic approach to business ethics: Insights from the study of Quaker employers. Journal of Business Ethics, 82(4), 835-850.

Walvin, J. (1997). The Quakers: Money and morals. London: John Murray.

Windsor, D. (1980). The Quaker enterprise: Friends in business. London: Muller.

Publisher's Note Springer Nature remains neutral with regard to jurisdictional claims in published maps and institutional affiliations. 